\title{
Resistance of the Postmodern Turkish Novel to the Return of Nationalism
}

\author{
Barış Yılmaz*
}

\begin{abstract}
My aim in this paper is to survey the journey of Turkey's postmodern historical fiction, referred to as "historiographic metafiction" by Linda Hutcheon (1988). This genre of postmodern fiction designates a narrative with two predominant features: (a) it is principally a retelling of a historical occurrence from a counter-position against the supposed factuality of the original story, and (b) it contains the self-reflexivity of its author, which enables him/her to question the boundary between fact and fiction, if there is any at all. Obviously, Hutcheon's conception of this particular category of postmodern fiction was mainly derived from an approach which stresses inherent narratological characteristics in the writing of history, as argued by Hayden White and other historiographers. My research questions in this study are: How successfully is historiographic metafiction used by postmodernist writers in Turkish literature? When we consider the rise of nationalism in Turkey and in the world, can postmodern literature offer an alternative to authoritative discourses? Has postmodernism been able to challenge traditional representations in Turkey? An analysis of selected works of contemporary Turkish literature will supply an answer to these questions.
\end{abstract}

Key words: Nationalism, Turkey, Turkish literature, postmodern literature, historiographic metafiction

* University of Szeged, Hungary; bryilmaz34@gmail.com 
The title might seem overly assertive when one thinks of the agonisingly shrinking significance of literature in Turkish society. Although books, especially novels, have never moved mountains, they have also never looked so desperate to find readers. According to a 2018 survey by Kadir Has University in İstanbul, reading frequency and habits among Turkish people are frightening. According to the survey results, $60.9 \%$ of participants said they do not read books, while $15.3 \%$ read once a month or less. The same survey points out that these figures were 52.8\% and 11.2\%, respectively, in 2017 (Aydin et al. $2018,112)$. The reason for the rapid decrease is difficult to conceive, but it is certain that the situation is not heading anywhere good.

Another inquiry conducted by the European Commission found that Turkey ranked last (at 38\%) on the "percentage of persons who have read at least one book in the last 12 months" among European Union members, EFTA (European Free Trade Association) states, and candidate countries. However, in 2011, Turkey no longer remained in last place, having passed Romania, whereas its rate dropped to 31\% (Mercy and BeckDomżalska 2016). Even though we can see a similar decrease for most other European countries, also due to the shortcomings of the Internet, it is still quite troublesome for Turkey to have such a small percentage. What is more troublesome is that it is easy to imagine that this figure has gradually fallen since 2011.

Apart from all these depressing statistics on reading frequency, students' reading performance does not look dazzling either. According to the 2015 PISA results, Turkey ranks far below average in reading performance among OECD countries. This data "measures the capacity to understand, use and reflect on written texts in order to achieve goals, develop knowledge and potential, and participate in society” (OECD 2019). 




Figure 1: PISA Results on Reading Performance for OECD Countries

There is no point in contemplating the topic further since the aim of this study is not to point out the omissions of the education system or cultural policies in a country with certain democratic issues. Nonetheless, the currently extreme 'nationalist' or 'chauvinist' tendencies in the country, perhaps even more than during any other period in its approximately 100 years of nation-state history, could raise questions regarding reading performance and frequency. Then why would anybody think the novel, especially the postmodernist novel, could offer resistance against the mighty armada of nationalism reinforced by the dual torpedoes of populism and conservativism? If there is potential for such resistance, what is the bona fide value of literature in a country where the majority of the population barely reads and barely understands what they read? I would like to answer these questions by indicating possible solutions in certain postmodern Turkish novels when dealing with increasing chauvinist nationalism in Turkey. Although reading rates are low, the sales rates for particular postmodern novels are surprisingly high. As a Nobel laureate writer, Orhan Pamuk (1952-) has never had trouble achieving bestseller status for a new novel. His latest, Kırmızı Saģlı Kadın (The Red-Haired Woman), saw its second printing only two weeks after it was published in 250,000 copies ("Krrmızı Saçlı Kadın İkinci Baskısını Yaptı” 2016). To date, it has achieved a 12th printing in Turkish and numerous editions in a number of foreign languages. Also, we must consider the untraceable number of digital copies either bought legally or downloaded illegally. It is difficult to say whether these sales figures depict a meaningful story of the reading rates for books. Even so, the numbers are sufficiently high to indicate a strong interest in postmodern Turkish literature. 
Then again, a place on the best-seller lists is not the exclusive privilege of Pamuk, who became a sensational figure right after revealing his "notorious" political opinions on "Turkey's dark past" and after winning the Nobel Prize in literature in 2006. Like Pamuk, certain other contemporary Turkish writers who have problematised controversial incidents in Turkish history by re-creating an alternative historical narrative have won the readers' favour. For example, İhsan Oktay Anar (1960-) has been highly acclaimed since the publication of his first novel Puslu Kitalar Atlast (The Atlas of Misty Continents) in 1995, which is an all-time best-seller with 53 printings and a number of editions over the period of 20 years. This novel has brought huge success to Anar and has been translated into French, German, Romanian, Hungarian, and Korean so far. In addition, a graphic novel version of the text, illustrated by İlban Ertem, was published in 2015 and was well received by fans.

With a 30th printing in the bookstores, Anar's second novel, Kitab-ül Hiyel (1996), meaning The Book of Deceptions, has also become another highly rated example of the postmodern historical fiction genre, containing inventions of the fictional - invented? - inventors in Ottoman history.

Anar narrates historical anecdotes predominantly from the era of the Ottoman Empire filled with mythical elements and fairy tale-like components. His constant commitment to reflecting himself within his own narratives through metafiction prompts us to question the borders between fact and fiction (Çokluk 2009, 126-127; Sagaster 2016, 165-169). In addition, a work of fiction containing both historical and autobiographical context disconcerts the self-assured factualness of historiography. Thus, Anar reinterprets the history of the people of Turkey through an ironic approach and creates a postmodern historiographic narrative (Yalçın Çelik 2005, 157).

Like Anar, Nedim Gürsel (1951-) gathers historical data as the historian does, only to merge it with his own autobiographical narrative and to bring it to the present day, in Boğazkesen: Fatib'in Romanı (1995, The Conqueror: A Novel). According to Aktulum (2015), in this novel the author rewrote the historical episode on a focal actor, Mehmed

1 It was in 2005 when Pamuk admitted to an "Armenian genocide" by stating "a million Armenians and 30,000 Kurds were killed in this country and I'm the only one who dares to talk about it." For his much-debated interview on this topic with Maureen Freely, his translator into English, see Maureen Freely, "I Stand by My Words. And Even More, I Stand by My Right to Say Them...” The Guardian, October 23, 2005, sec. World news, accessed February 10, 2019. https://www.theguardian.com/world/2005/oct/23/books.turkey. However, Pamuk's courageous statement and his insistence on standing by freedom of speech rewarded him with a court case on "insulting Turkishness" based on the infamous Article 301 in the Turkish constitution; see Reuters, "Popular Turkish Novelist on Trial for Speaking of Armenian Genocide," The New York Times, December 16, 2005, sec. World, accessed February 10, 2019. https://www.nytimes.com/2005/12/16/world/europe/popular-turkish-novelist-on-trial-forspeaking-of-armenian.html. 
II, within a new context. By coalescing this kind of metafiction with countless historical data, he forms a hybrid side-story over the writing process and its troubles. Ultimately, the novel has been historicised, while the history has been fictionalised (Aktulum 2015, 3). Gürsel maintained the same tendency of re-narrating the past in his Resimli Dünya (2004, The World in Images), and Allab'in Kizlarl (2008, The Daughters of Allab). The latter book, which was set mainly during the time of Muhammed before Islam was established in the early 7 th century, drew attention with its provocative content so that Gürsel was put on trial for "humiliating the religious values of part of the people" and "inciting the people to hatred" - though he was acquitted in June 2009, according to a report by the Initiative for Freedom of Expression ("Author Nedim Gürsel Acquitted of 'Humiliating' Religion” 2009). A dual citizen of both France and Turkey, Gürsel has published novels in French as well as in Turkish. His writings have been translated into a number of languages, such as English, Spanish, and German.

Hasan Ali Toptaş (1958-) is another postmodernist Turkish novelist who constantly intertwines fiction with reality in his novels. Fantastic elements play a very important role in his fiction insofar as they lose their fantasticality and access to reality as happens in magical realism. In his 2013 novel Heba (Reckless), Toptaş touches some sensitive nerves that every adult Turkish man has in a way, for example, concerning patriarchal initiation processes towards adulthood in a traditional society. The protagonist of the novel, Ziya, starts his initiation in the friendship chamber in his neighbourhood by killing birds, which will return to him when he grows up. Then, he must complete his compulsory military service and stop border trespassers - smugglers or terrorists, or mules and goats - to be accepted as a man in society. Surely, this inflicts another trauma. Also, he is required to marry and be a good husband to comply with societal expectations, but his forced marriage becomes a grave failure, which traumatises him again. Like the novels above, there are strong autobiographical implications and self-reflexive elements in this book. At some point, the focus shifts to the protagonists' early youth when he served as a soldier in a border patrol unit in Turkey's southeast. His duty was to stop smugglers from entering Turkey, but he alone seems indignant about the army officers' unjust treatment of the local people, the Kurds. This novel, especially the "Border" chapter, is a cogent questioning of Turkey's methods of counter-terrorism in the 1990s, as well as in the present (Çetin 2015, 68).

Shortly after its publication, Heba was translated into English as Reckless by Maureen Freely, into Dutch as Verloren levens by Hamide Dogan, and into Italian as Impronte by Giulia Ansaldo and, since then, has found audiences all over the world.

Ömer Zülfü Livaneli (1946-), who is renowned for his work as a musician and politician as well, has written numerous novels with postmodernist tendencies that engage 
with political contexts, especially regarding Turkey's political conundrums. Being a political activist, Livaneli has long fought against the violation of human rights and freedom of speech in Turkey. Consequently, he was given a UNESCO goodwill ambassador post in 1995. Due to his reputation for impartiality, his name has been touted by the Social Democratic Party (CHP) as a natural candidate for the presidency several times although this has never materialised. At least his novels have attracted widespread attention in Turkey and in the world. According to the biographical information on his personal website, Livaneli's novels have been translated into 37 languages and he has won "numerous Turkish and international literary awards." ("About," n.d.)

In Mutluluk (2002, Bliss: A Novel), which was adapted for the cinema in 2007 with an original soundtrack by Livaneli himself, the author visits the traumas ingrained in Turkish society concerning gender, customs, and social roles - not within a particular timeframe, but within a paradigm that casts light on a long-lasting state of distress in the country. Specifically, killings in the name of honour or morality among the traditional communities in eastern Turkey were called into question in this novel. Shifting the perspective towards women's troubles even within a minority group confronted with injustice, Livaneli attempts to speak out on behalf of the subalterns in Turkey and expands a comprehensive reading on gender inequality and social traumas (Avcı, Koç, and Bayar 2016, 27).

What traumas are we speaking about here? They mostly lie in Turkey's past. Turkey, once a big empire with a multinational structure, experienced the binary positions of nationalism during and after its War of Independence (1919-1922) against the Allied Powers. Before World War I, as the Ottoman Empire, it had strived to protect its vast territories through the Ottomanist ideal of equality for every citizen of the Empire without any religious or ethnic division. However, in the end, this and other overarching ideas, such as Islamism and Westernism, could not hold out against the aura of nationalism. First, the Ottoman Empire started to lose its Balkan territories subsequent to a series of nationalistic revolts, then the heavy loss of World War I occurred. The intelligentsia was already offering the solution of Pan-Turkism. Meanwhile, the imperial powers were attempting to divide the country among its neighbours and stateless subjects, and then to colonise the remaining parts. However, these attempts only helped to consolidate the intelligentsia around the idea of nationhood. Winning the Turkish War of Independence that occurred right after the end of World War I, Mustafa Kemal Atatürk (1881-1938) and his staff officers established the Turkish Republic in 1923 based on the incorporation of the following elements: one nation (Turks), one language (Turkish), one religion (Islam), and one sect (Sunnism). The concept was similar to some other nation-state building processes in the world; initially, it involved the depor- 
tation/extermination of people with a different religious identity (Greeks, Armenians, Jews, and Christian Turks) and the assimilation of people with a different ethnic identity (Kurds, Circassians, the Laz people, and Zazas) or of people from a different sect of Islam (the Alevi), all in the melting pot of a Turkish-Islamic synthesis. Still, even after all the efforts to homogenise the country, a significant number of cultural, ethnic, and religious minorities remained in the country outside the circuit of representation. The emergence of postmodernism has shifted this paradigm, preoccupied with the reproduction of the practices of the dominant discourse. Against the canonised robustness of the modernist representation and referentiality, postmodern fiction, by availing itself of post-structuralism, offers to turn the tables in favour of the oppressed.

I believe these examples from contemporary Turkish literature to be a sufficient display of the interest among readers both in Turkey and in the world in this kind of postmodernist novel constructed in a historical and political context. Despite the fact that reader numbers, reading rates, and reading efficiency are decreasing rapidly, all these novels and writers can find a certain audience demanding an alternative narrative to the official bistorical facts. The authors of these novels and their counterparts in world literature, for instance, John Fowles (1926-2005) and his French Lieutenant's Woman (1969), Salman Rushdie (1947-) and his Midnight's Children (1981), and Margaret Atwood (1939-) and her Blind Assassin (2000), deliberately or not, generate significant questions:

- The first question is epistemological: Why should we accept historical novels as being less reliable than historiography in terms of narrating the past? To put it more explicitly, how do we decide that the authors are not depicting a realistic image of the past since they practically process similar stages as those of historians in narrative construction?

- The second question deriving from the first is ontological: Where does the boundary between fact and fiction start when we think about the overt self-reflexive aspect of these novels combined with historical references, not only in literature, but also in life itself?

The answers can be found in the postmodern literary and historical theories, beginning with Hayden White's Metahistory and Linda Hutcheon's A Poetics of Postmodernism. Especially when we take into account the role of traditional historical novels in the rapid spread of nationalism in the late $19^{\text {th }}$ and early $20^{\text {th }}$ centuries, the postmodern historical novel, or historiographic metafiction, as coined by Linda Hutcheon, forms an alternative narrative and builds a point of resistance against the perpetual return of nationalism. I am aware that nationalism never withdraws but subsides or intensifies in accordance 
with the international or national political climate in a country like Turkey where the population is manipulated relentlessly by the conventional media in a bid to conceal "class interests" as "national interests." (Hall 1980, 138). Nationalism never withdraws but subsides or intensifies in accordance with the international or national political climate. Certainly, it is not inaccurate to claim that both the national and international political climates are currently swelling with nationalism. Moreover, this is not constructive nationalism or patriotism, but a blind patriotism associated with one's rigid attachment to one's country "by unquestioning positive evaluation, staunch allegiance, and intolerance of criticism." The constructive patriot opens a kind of criticism for the sake of nationalist interests (Schatz, Staub, and Lavine 1999, 153). The nationalism we have faced in the past 5 to 10 years and its close associate, right-wing populism, remind us of the nationalism of the $19^{\text {th }}$ century or that of the pre-war conditions with their excessive media propaganda.

The novel and historiography crucially contributed to the expansion of $19^{\text {th }}$-century nationalism in Europe and its periphery. While Anderson asserted that the novel and the newspaper - print capitalism - were the technical instruments by which nationalism could represent "the kind of imagined community that is the nation," (Anderson 2006, 25, 47), Hobsbawm and Kertzer (1992) stressed the pivotal role of historiography for the spread of nationalism, arbitrary or not:

For historians are to nationalism what poppy-growers in Pakistan are to heroin-addicts: we supply the essential raw material for the market. Nations without a past are contradictions in terms. What makes a nation is the past, what justifies one nation against others is the past, and historians are the people who produce it. So my profession, which has always been mixed up in politics, becomes an essential component of nationalism. (3)

On the other hand, the historiographic metafiction of postmodernism, in one single form, undermines the firm legitimacy of authoritative nationalism provided by the conventional media, traditional novels, and history books. Through historiographic metafiction, a new narrative is created, or rather an old one is re-narrated from an "ex-centric" perspective, that of the marginal, of the outsider, of the minority, or of the subaltern against the homogenous perspective of modernity's monolithic narratives (McHale 2004, 6-7). In this respect, historiographic metafiction incorporates representations of suppressed identities, for instance, as we encounter in postcolonial or women's writing (Hutcheon 1988, 12, 230). Then, we can confidently suggest that the postmodern novel is neither apolitical nor nostalgic as it has been written off by its opponents, namely by Fredric Jameson and Terry Eagleton. Jameson blamed postmodernity for bringing forth 
a number of devastating phenomena, such as "a new depthlessness," "a consequent weakening of historicity," "a whole new type of emotional ground tone," "a whole new technology," and "a whole new economic world system" (Jameson 1991). Meanwhile, Eagleton claimed that in opposing certain notions of the Enlightenment, namely "truth, reason, identity, and objectivity, of the idea of universal progress or emancipation, of single frameworks, grand narratives, ultimate grounds of explanation," postmodernity conceives the world as "contingent, ungrounded, diverse, unstable, indeterminate, a set of disunified cultures or interpretations which breed a degree of scepticism about the objectivity of truth, history and norms, the givenness of natures and the coherence of identities," a world marked by a new form of capitalism, consumerism, and de-centredness, and thus postmodernity switches the focus of political thinking from class struggle to “identity politics" (Eagleton 1996, vii).

Notwithstanding Marxist critics' point that over-emphasising identity politics distracts the attention of the resistance from the world's more fundamental problems (especially the non-Western world), postmodernist scepticism over the reason, norms, and institutions of positivism has made us aware that all of these notions were built on a Western culture-centric understanding. Moreover, the institutions themselves were brought into being through the "social imaginary," or "instituting society," according to Castoriadis ([1975] 2005, 369).

If we return to history as an essential part of the social imaginary, Hayden White's ground-breaking book Metahistory will be the primary source to understand the narrative structure of historiography. White examined the "common roots of literature and historiography" to reveal the methods and strategies of narratology used by historians. As a determining factor in his theory, White emphasises the distinction between historian and imaginative writer on being dependent on invented or actual events; however, they both employ a narrative with like techniques when they compose their work (Korhonen 2006, 8). In addition, White ([1973] 2014) suggested that there is always an implicit ideology in the historian's interpretation of the past since it is not a science:

There does, in fact, appear to be an irreducible ideological component in every historical account of reality. That is to say, simply because history is not a science, $[. .$.$] the very claim to have discerned some kind of formal$ coherence in the historical record brings with it theories of the historical world and historical knowledge itself which have ideological implications for attempts to understand "the present", however this "present" is defined. (21) 
Thus, it was no more difficult to revisit historical events from a different ideological standpoint, this time being intentionally catalysed by the ideology, while evading allegations of not relying on the facts. White's theories paved the way for New Historicism by putting into action even more radical and overarching assumptions on the interpretation of cultural history, among which the one most related to our topic is that "literary and non-literary 'texts' circulate inseparably" (Veeser 1989, xi). We must keep in mind that all these postmodern approaches to history, literature, and institutions of modernity in general have enhanced autonomy among writers as well as the historical topics they persist in re-creating.

It is time for the merits of the postmodern Turkish writers who have engaged with even the most fragile fragments of recent or distant Turkish history to be considered more carefully. Under the domination of imprudent, blind nationalist discourses, the historiographic metafiction of Turkish literature offers resistance by telling unofficial yet valid stories of the past. It gives a voice to those who have not been represented before, and it makes use of both irony and parody to undermine the sturdy base of official historiography. In the future, it will resist not only with the novel, but also with series, films, and the visual arts, since the dominant power uses the same means to substantiate its claims.

\section{References}

“About.” n.d. O.Z. Livaneli's Official Website. Accessed 10 September 2019. http://livaneli.net/about/.

Aktulum, Kubilay. 2015. "Romanesk Söylemin Tarihselleştirilmesi ya da Tarihi Yeniden Yazmak," Bilig 73: 1-16.

“Author Nedim Gürsel Acquitted of 'Humiliating' Religion.” 2009. IFEX. July 14, 2009. Accessed 10 September 2019. https://www.ifex.org/turkey/2009/07/14/gursel_acquitted/.

Avc1, Özlem Haskan, Muharrem Koç, and Öznur Bayar. 2016. "Zülfü Livaneli'nin Mutluluk Romanı Karakterlerinin Toplumsal Cinsiyet Bağlamında İncelenmesi.” İnsan Eீ İnsan 3, 8 (Spring): 27.

Aydın, Mustafa, Mitat Çelikpala, Cihan Dizdaroğlu, Banu Baybars Hawks, Murat Güvenç, Emrah Karaoğuz, Mustafa Gökcan Köse, and Basri Alp Akıncı. 2018. “Türkiye Sosyal-Siyasal Eğilimler Araştırması-2018.” İstanbul: Kadir Has University Center for Turkish Studies.

Castoriadis, Cornelius. (1975) 2005. The Imaginary Institution of Society. Translated by Kathleen Blamey. Cambridge, Malden: Polity Press.

Çetin, İclal. 2015. “Reckless.” World Literature Today 89 (6): 68.

Çokluk, Necmiddin. 2009. “İhsan Oktay Anar ve Romanları Üzerine Bir İnceleme.” MA, Edirne: Trakya University.

Eagleton, Terry. 1996. The Illusions of Postmodernism. Malden, Oxford, Victoria: Blackwell. 
Freely, Maureen. 2005. “I Stand by My Words. And Even More, I Stand by My Right to Say Them...” The Guardian, October 23, 2005, sec. World news. Accessed 10 September 2019. https://www.theguardian.com/world/2005/oct/23/books.turkey.

Hall, Stuart. 1980. “Encoding/Decoding.” In Culture, Media, Language, edited by Stuart Hall, Dorothy Hobson, Andrew Lowe, and Paul Willis, 128-38. London: Routledge.

Hobsbawm, E. J., and David J. Kertzer. 1992. "Ethnicity and Nationalism in Europe Today.” Anthropology Today 8 (1): 3-8.

Hutcheon, Linda. 1988. A Poetics of Postmodernism: History, Theory, Fiction. London: Routledge.

Jameson, Fredric. 1991. Postmodernism, or, The Cultural Logic of Late Capitalism. Durham: Duke University Press.

“Kırmızı Saçlı Kadın İkinci Baskısını Yaptı.” 2016. Http://Kitap.Ykykultur.Com.Tr. February 17, 2016. Accessed 10 September 2019. http://kitap.ykykultur.com.tr/basin-odasi/haberlerduyurular/2016/kirmizi-sacli-kadin-ikinci-baskisini-yapti.

Korhonen, Kuisma. 2006. “General Introduction: The Literature/History Debate.” In Tropes for the Past: Hayden White and the History/Literature Debate. Amsterdam, New York: Rodopi.

Mercy, Jean-Louis, and Marta Beck-Domżalska, eds. 2016. Cultural Statistics. 2016 ed. Luxembourg: Publication Office of the European Union.

OECD. 2019. “Reading Performance(PISA) (Indicator).” Accessed 10 September 2019. https:// data.oecd.org/pisa/reading-performance-pisa.htm.

Reuters. 2005. "Popular Turkish Novelist on Trial for Speaking of Armenian Genocide.” The New York Times, December 16, 2005, sec. World. Accessed 10 September 2019. https://www. nytimes.com/2005/12/16/world/europe/popular-turkish-novelist-on-trial-for-speaking-ofarmenian.html.

Sagaster, Börte. 2016. “'Me, Who Got into the Text, Me, Who Became the Text': Encounter of Fact and Fiction in Contemporary Turkish Autobiographical Writing.” In Autobiographical Themes in Turkish Literature: Theoretical and Comparative Perspectives, edited by Olcay Akyıldız, Halim Kara, and Börte Sagaster, 165-169. Würzburg: Orient-Institut Istanbul.

Schatz, Robert T., Ervin Staub, and Howard Lavine. 1999. "On the Varieties of National Attachment: Blind versus Constructive Patriotism.” Political Psychology 20 (1): 151-174.

Veeser, H. Aram. 1989. "Introduction.” In The New Historicism, edited by H. Aram Veeser, ix-xvi. London, New York: Taylor \& Francis.

White, Hayden. (1973) 2014. Metabistory: The Historical Imagination in Nineteenth-Century Europe. Baltimore: Johns Hopkins University Press.

Yalçın Çelik, Dilek. 2005. “Eski Zaman Mucitlerinin Inanılmaz Öyküleri Kitabü’l Hiyel: Hiyel Mi Yoksa Hayal Mi?” In Yeni Taribselcilik Kuramı ve Türk Edebiyatında Post-Modern Tarib Romanları. Ankara: Akçağ Yayınları. 